UNDERGRADUATE RESEARCH IN NATURAL AND CLINICAL SCIENCE AND TECHNOLOGY (URNCST) JOURNAL Read more URNCST Journal articles and submit your own today at: https://www.urncst.com

\title{
Bacteriophage-Liposomes Complex, a Bi-therapy System to Target Streptococcus pneumonia and Biofilm: A Research Protocol
}

David Jung, BSc [1]*, Antoine Gaudreau-Lapierre, BSc [1], Emran Alnahhas, BSc [1], Samy Asraoui, BSc [1]

[1] Faculty of Medicine, University of Ottawa, Ottawa, Ontario, Canada, K1H 8M5

*Corresponding Author: djung084@uottawa.ca

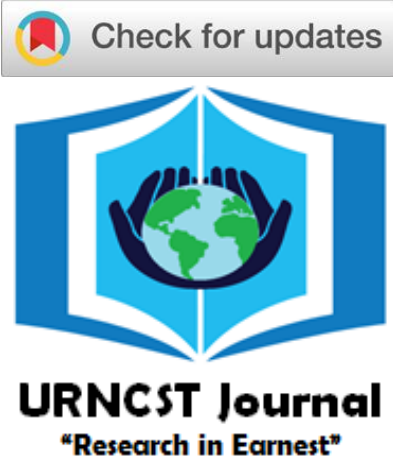

\begin{abstract}
Introduction: Streptococcus pneumoniae is a gram-positive bacterium, which is the leading cause of death for young children, elderly population, and immunocompromised patients. Its ability to mutate and become resistant to some of the strongest antibiotics makes them difficult to treat and increases the risk of disease spread. Although the development of stronger antibiotics to treat such microbes may be an option, they potentially pose a dangerous threat to the body. As such, a viable treatment option to fight against antimicrobial resistance has yet been found.

Methods: The study focuses on utilizing a bi-therapy system to target $S$. pneumoniae in biofilm, which is the site of emerging antibiotic resistant mutants, by creating levofloxacin-liposomes carrying phages and testing them both in vitro and in vivo.

Anticipated results: Using bacteriophage therapy and applying bacteriophage-antibiotic synergy, it is hoped to augment the potency of the treatment while lowering its side-effects. The Cp-1 bacteriophage-liposomes complexes are expected to be specific to the $S$. pneumoniae to carry antibiotics to sites of infection.

Discussion: The therapy could ensure targeted bacterial lysis and site-directed delivery of low-dose drugs to decrease the toxicity effect of the antibiotics. Once the efficacy is established and is proven to be significant, its potency can be tested in $\mathrm{BALB} / \mathrm{cByJ}$ mice models before bringing this therapy to animal trials then human clinical trials.

Conclusion: Bacteriophages are very attractive therapeutic agents that effectively target pathogenic bacteria, safe for the human body, and highly modifiable to combat newly emerging bacterial threats. In addition to its many benefits, the use of bacteriophages could significantly reduce healthcare costs. The potential use of bacteriophages-liposomes complexes could be translated to treat respiratory infections in humans after confirming its efficacy in vitro and in vivo studies.
\end{abstract}

Keywords: biofilm; Streptococcus pneumoniae; bacteriophage Cp-1; antibiotic-resistance; antibiotic liposome delivery; pneumococcal infection

\section{Introduction}

Streptococcus pneumoniae infection has been the leading cause of death for children under the age of five, and a contributing factor to the mortality rates of elderly and immunocompromised patients [1-3]. This grampositive bacterium primarily spreads through airborne droplets resulting in millions of infections and over one million deaths per year [4]. Furthermore, some pneumococcal infection survivors can later develop longterm complications, including loss of hearing, neurological deficits, and neuropsychological impairments [5-7].

$S$. pneumoniae acts as an opportunistic pathogen and can infect the human nasopharynx before migrating to the lower airways and other lung tissues leading to respiratory infections [8]. Nasopharynx infection by S. pneumoniae is typically asymptomatic and its colonization of the host precedes disease [5,9]. Previous work demonstrated that pneumococcal biofilm formation begins during nasopharyngeal colonization [10]. These biofilms are structures composed of microbial cells, extracellular polymeric substances, and provide an environment for the genetic exchange of materials to increase antimicrobial resistance [11]. Their matrix, composed primarily of polysaccharides, is resistant to antibiotics and is associated with chronic infections [12]. S. pneumoniae strains that are effective colonizers of the nasopharynx are known to be better at forming biofilms and biofilm-specific antibacterial resistance on epithelial cells than other colonizer strains [13-15]. Collectively, these findings underlie how $S$. pneumoniae biofilm is formed and established before a patient is diagnosed for therapy.

$S$. pneumoniae infections are typically treated using beta-lactam and fluoroquinolone (e.g., levofloxacin) antibiotics [16]. They work by preventing DNA replication in bacteria and causing bacterial cell death [17]. While traditional antibiotic treatment might be bactericidal against 
the planktonic form of $S$. pneumoniae, it becomes ineffective in the face of biofilm-specific antibacterial resistance of the $S$. pneumoniae biofilm [18-20]. Increased resistance, in this regard, is partially due to the reduced infiltration of antibiotics into the biofilm structure but is more likely attributed to adaptive phenotype changes of the biofilm bacteria [4,21,22]. Additionally, the biofilm environment provides a fertile ground for the emergence of antibiotic-resistant $S$. pneumoniae mutants; the mutation rate of cells in biofilms is higher than planktonic cells [22]. These mutations give rise to antibiotic-resistant strains due to modifications of the antibiotic-targeted proteins, antibiotic drugs, or antibiotic transport [23]. Resistant strains have been reported for both aforementioned familydrugs further reducing the ability of antibiotic-based therapy to eliminate $S$. pneumoniae infections. To that end, the breakdown of formed biofilm provides for an appealing therapeutic intervention against $S$. pneumoniae infection.

With the antibiotic resistance crisis and urgent search for alternative clinical treatments for bacterial infections, bacteriophages have re-emerged as a promising alternative to antibiotics for clinical use [24,25]. Bacteriophages are viruses that infect bacteria to hijack the cell's machinery and reproduce new phages. After new bacteriophages are assembled, they begin lysing the cell to burst out and infect nearby bacteria [26]. Bacteriophage's inability to interact directly with eukaryotic cells [27] suggests that they cannot infect human cells and are possibly safe for therapeutic use.

Bacteriophages targeting and eliminating $S$. pneumoniae have successfully been identified and isolated [25]. However, in the context of biofilm degradation, only bacteriophage-encoded enzymes have been tested against $S$. pneumoniae [28]. In particular, Cpl-1 and Cpl-7 lysozymes derived from $\mathrm{Cp}-1$, a $S$. pneumoniae-specific lytic bacteriophage, were found to induce bacterial cell lysis and biofilm degradation [25,28,29] (Figure 1). Furthermore, the synergistic approach of phage therapy with antibiotics has displayed efficient elimination of several bacterial infections [30-32], though this is yet to be demonstrated for S. pneumoniae. infections.

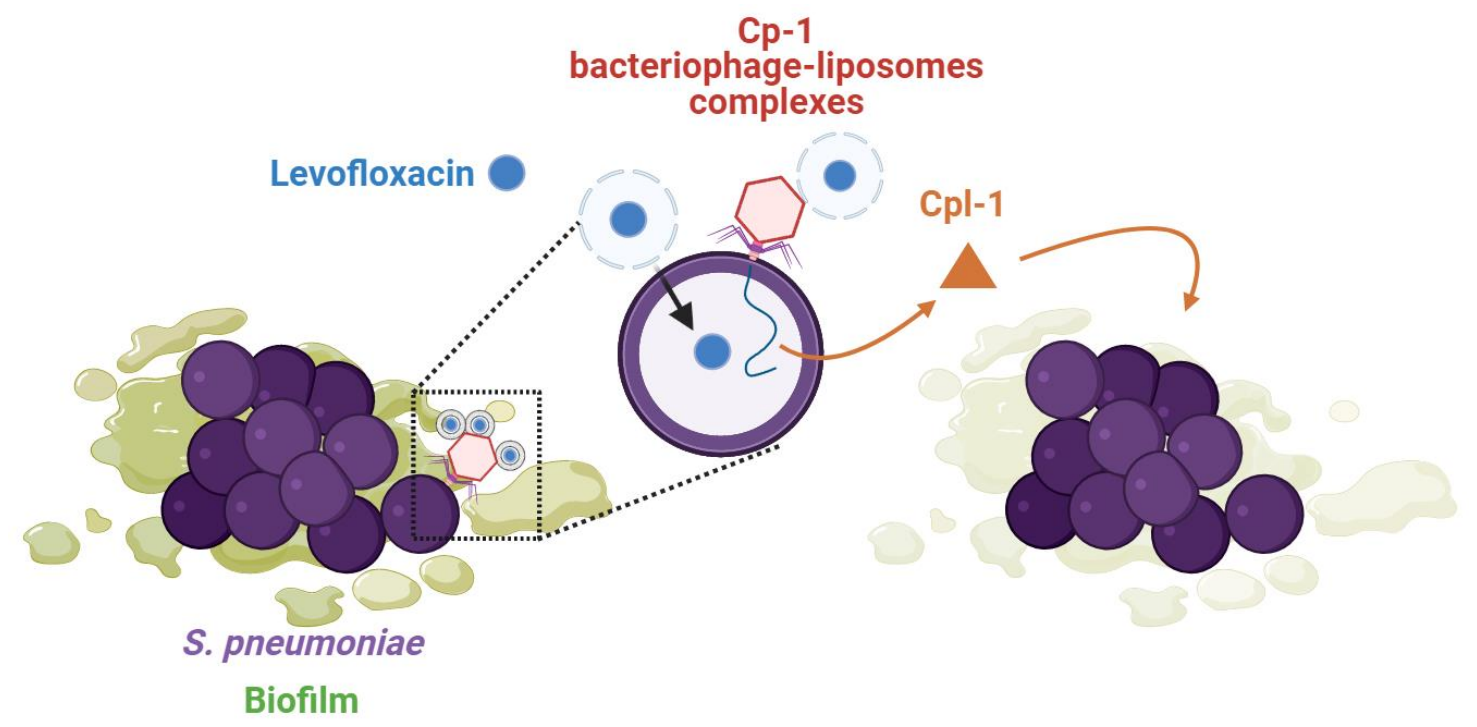

Figure 1. Outline of Cp-1 bacteriophage-liposome complexes' mechanism of action. The Cp-1 bacteriophage selectively targets $S$. pneumoniae and localizes the levofloxacin-containing liposomes to the sites of bacterial infection. Both levofloxacin and bacteriophage genome enter the bacterial cell, leading to its death. Additionally, the bacteriophage genome encodes for the Cpl-1 enzyme, which is capable of degrading the surrounding biofilm.

Lipid vesicles as drug carriers are currently one of the most promising delivery approaches for antibiotics [33,34]. Antibiotic-loaded liposomes have previously received US Food and Drug Administration (FDA) approval for clinical use due to their improved pharmacokinetics, biodistribution, decreased toxicity and lack of immune system activation [34-37]. Moreover, liposomes loaded with an active compound can be coupled with bacteriophages [38]. Notably, the composition of the liposome and its similarity to the bacterial membrane mediates their fusion. The process promotes accumulation of the antibiotic within the bacteria consequently bypassing several mechanisms of antibiotic resistance [39].

Therefore, we hypothesize that using $\mathrm{Cp}-1$ as a biofilm-degrading bacteriophage to deliver antibioticloaded liposomes offers an effective and novel strategy in overcoming biofilm-based $S$. pneumoniae infections. Here, we describe the formation of $\mathrm{Cp}-1$ bacteriophage-antibioticloaded liposomes complexes, dubbed Cp-1 LevoLipo, and the efficiency of this novel bi-therapy, both in vitro and in vivo, against $S$. pneumoniae infections. The use of this therapy would not only ensure biofilm breakdown but also 
UNDERGRADUATE RESEARCH IN NATURAL AND CLINICAL SCIENCE AND TECHNOLOGY (URNCST) JOURNAL Read more URNCST Journal articles and submit your own today at: https://www.urncst.com

antibiotic localization and accumulation at the site of $S$. pneumoniae infection (Figure 1).

\section{Methods}

Cp-1 bacteriophages have been shown to infect $S$. pneumoniae [40] and disrupt the biofilm. Thus, using them to develop bacteriophage-liposomes complexes seems like a potential synergistic therapeutic avenue. Using the detergent depletion technique [41] combined with antibiotic addition, positively charged liposomes containing levofloxacin would be generated. They would then be conjugated with negatively charged $\mathrm{Cp}-1$ bacteriophages [38] to obtain Cp-1 bacteriophage-liposomes complexes.

\section{LevoLipo Complexes Formation}

To create the liposomes, levofloxacin powder would be added to a mixture of 1,2-dioleoyl-3-trimethylammonium propane chloride (DOTAP) and 1,2-dioleoyl-snglycerophosphocholine (DOPC) lipids dissolved in chloroform (30:70 mass ratio of DOTAP/DOPC) at a ratio of 1:100 (levofloxacin to lipids). This mixture would then be dried with a nitrogen evaporator, which should leave a transparent film at the bottom of the tube. Once dried, a phosphate buffer $\left(10 \mathrm{mM} \mathrm{NaH} \mathrm{PO}_{4}, \mathrm{pH} 7.0,100 \mathrm{mM} \mathrm{NaCl}\right)$ containing cetyltrimethylammonium bromide (CTAB) would be added to the film obtained previously to a molar ratio of 3:1 (CTAB/lipids-levofloxacin molar ratio). Following CTAB addition, the samples would be sonicated and dialyzed in phosphate buffer, then eluted through Sephadex G-50 beads to get rid of excess CTAB [38] (Figure 2) and purify the liposomes carrying levofloxacin (LevoLipo).

\section{Cp-1 Phage Coupling to LevoLipo Complexes}

To allow the $\mathrm{Cp}-1$ phage to carry the positively charged liposomes, a capsid protein will need to be modified to have a negatively charged region. The targeted capsid protein is gp9, which composes the majority of the phage proteins at around $90 \%$ of total proteins. Addition of 8 glutamic acids would create a negatively charged region at the C-terminus of gp9, as its first 48 amino acids have been shown to be cleaved off [40], using a PCR mutagenesis-based approach (Figure 2). To form the complex of phage-liposomes (Cp-1 LevoLipo), simply mix the negatively-charged mutated phages with the positivelycharged purified liposomes [38] (Figure 2).

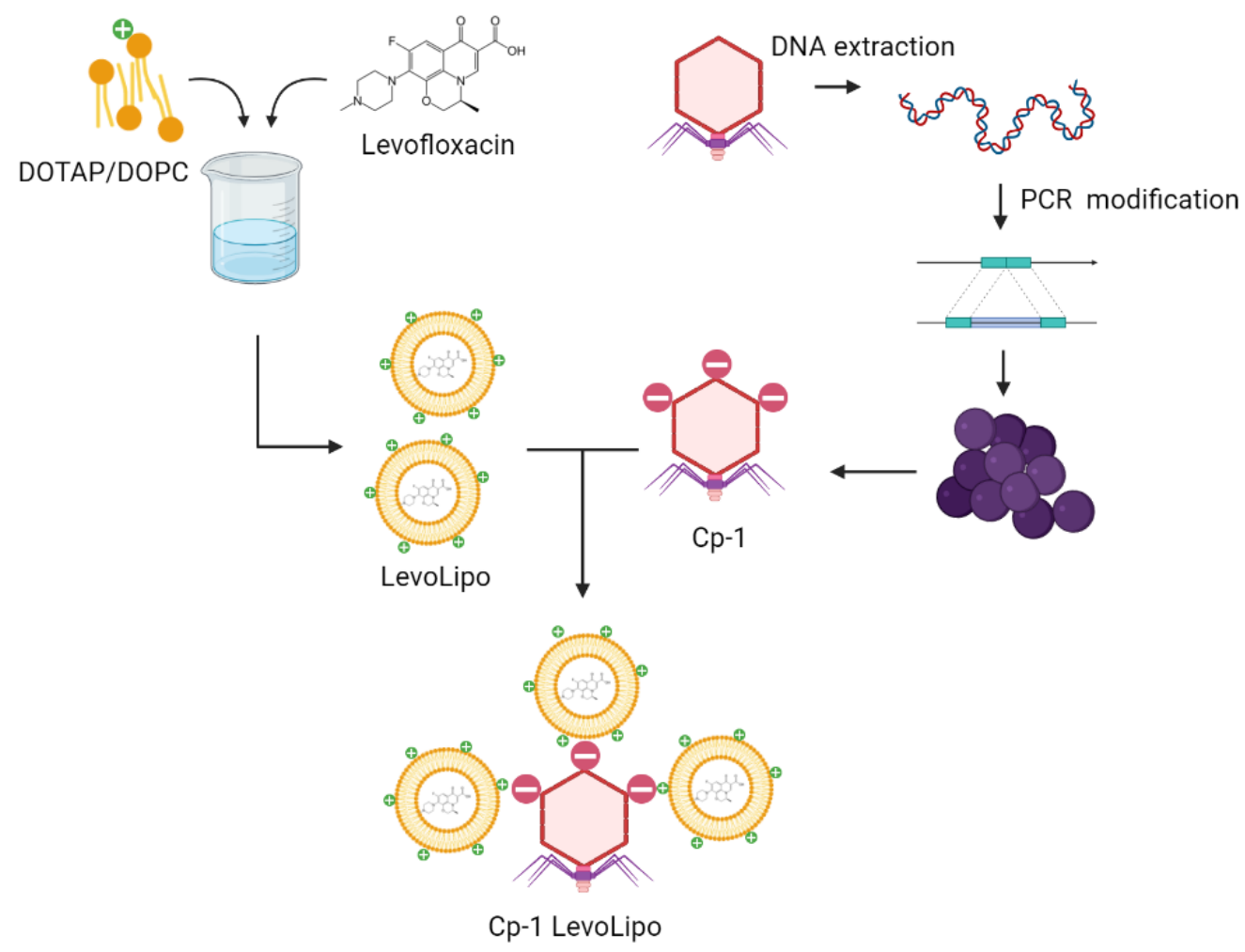

Figure 2. Formation of Cp-1 LevoLipo bi-therapy system. To generate the LevoLipo particles, DOTAP and DOPC lipids would be mixed with levofloxacin powder. After drying this mixture, the pellet would then be re-solubilized with a detergent (CTAB). To generate the negatively charged Cp-1 phages, a PCR based approach would be utilized to add eight glutamic acids to the $\mathrm{C}$-terminal region of the gp9 protein using the purified $\mathrm{Cp}-1$ DNA. Once the modifications are added to the gene, they would be stitched back in the bacteriophage DNA and transformed in S. pneumoniae to generate the new modified bacteriophage. These charged phage particles and LevoLipo particles would then be mixed together to generate the bi-therapy system. 
UNDERGRADUATE RESEARCH IN NATURAL AND CLINICAL SCIENCE AND TECHNOLOGY (URNCST) JOURNAL Read more URNCST Journal articles and submit your own today at: https://www.urncst.com

To confirm that the complexes are formed, the samples would be fixed onto a copper grid using $1 \%$ glutaraldehyde for 5 mins at room temperature and stain using $2.5 \%$ phosphotungstic acid and $2.5 \%$ trehalose at $\mathrm{pH}$ 7.0. Then, the Cp-1 LevoLipo complexes would be imaged by transmitted electron microscopy [38].

\section{Bactericidal Activity Testing of Cp-1 LevoLipo Complexes} $\underline{\text { In Vitro }}$

To test the bactericidal efficiency of each treatment in vitro, bacterial lawns of $S$. pneumoniae will be used for the antibiogram test [42]. The test consists of placing filterpaper disks imbued with different concentrations of levofloxacin (standards from company), the solution of levofloxacin-liposomes (LevoLipo), the solution of $\mathrm{Cp}-1$ bacteriophages, or of the solution containing $\mathrm{Cp}-1$ bacteriophages carrying levofloxacin-liposomes (Cp-1 LevoLipo) on blood agar plates of bacterial lawns
(Figure 3). After incubation at $37^{\circ} \mathrm{C}$ with $5 \% \mathrm{CO} 2$ for 24hrs, the growth inhibition zones formed around the filterpaper disks would be measured. By comparing the $\mathrm{Cp}-1$ LevoLipo inhibition zones to the levofloxacin standards, an optimal concentration of $\mathrm{Cp}-1$ LevoLipo will be determined for follow-up in vivo experiments. The same experiment would also be repeated with $S$. pneumoniae in biofilm models using the same protocol. To favor biofilm formation of $S$. pneumoniae, the bacteria would be grown in ToddHewitt broth supplemented with $500 \mu \mathrm{M}$ of zinc [43] prior to transfer the newly made biofilm onto blood agar plate to create a bacterial lawn (Figure 3). Each in vitro experiment will be repeated at least 3 times (biological replicates). Once Cp-1 LevoLipo complexes are confirmed to be more effective at eliminating $S$. pneumoniae in vitro than the other treatments, an in vivo assay to assess infection treatment will be carried out.

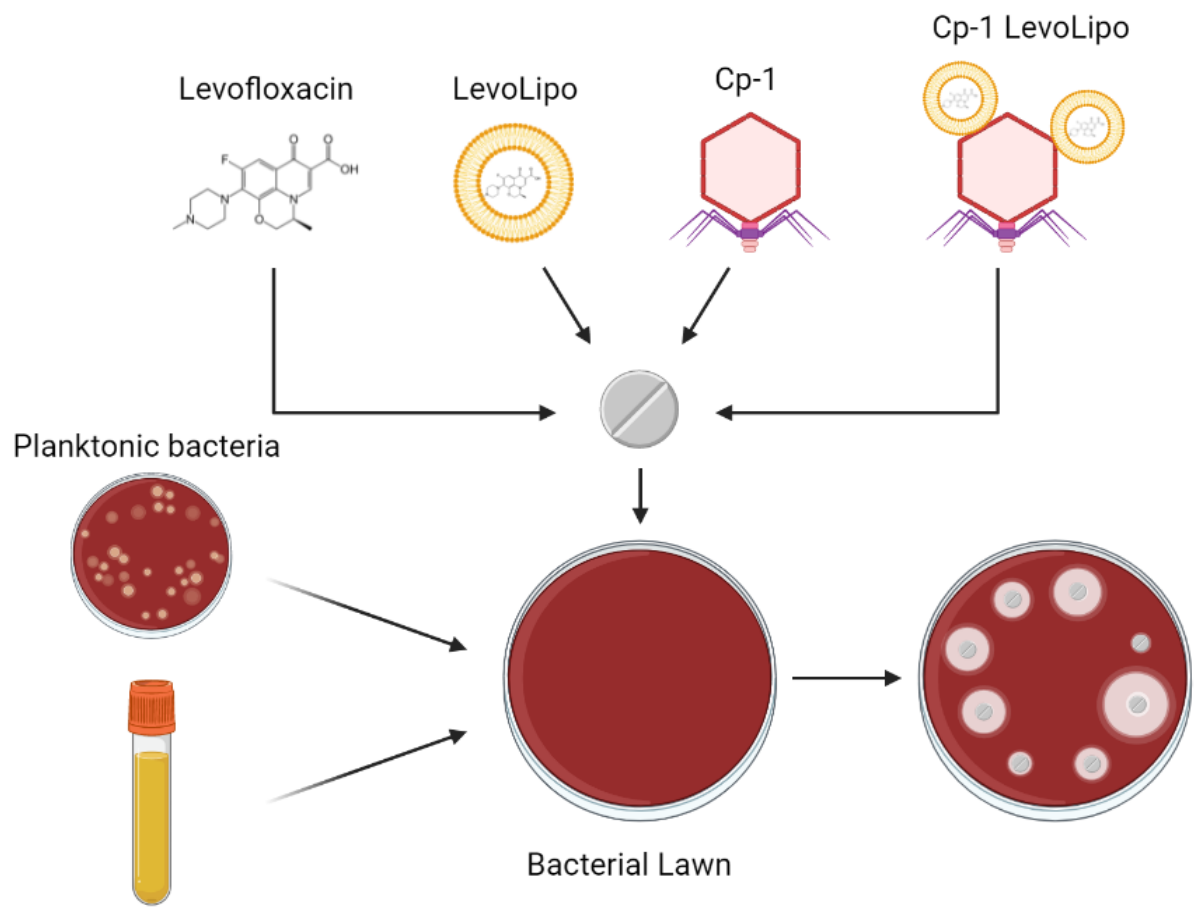

Biofilm bacteria

Figure 3. Assessment of Cp-1 LevoLipo bi-therapy system's ability to kill S. pneumoniae bacteria in vitro. Filter-paper disks loaded with either Levofloxacin, LevoLipo, $\mathrm{Cp}-1$, or $\mathrm{Cp}-1$ LevoLipo would be incubated on bacterial lawns of blood agar plates. The degree of growth inhibition surrounding each filter paper would be used to measure treatment effectiveness. Additionally, in vitro experiments would also be repeated to measure treatment effectiveness in the presence of biofilm. The biofilm formation would be stimulated by growing the bacteria in Todd-Hewit broth in presence of zinc.

In vivo Bactericidal Activity of Cp-1 LevoLipo Complexes

Next, a set of in vivo experiments would be carried out to assess the effectiveness of the bi-therapy system and to monitor potential side effects. A previous study has detailed the infection of the BALB/cByJ mice with $S$. pneumoniae and confirmed the formation of biofilm in vivo [10]. Using this same protocol, 6-12-week-old female mice will be infected via intranasal injection of $5 \times 10^{6}$ colony forming unit (CFU) of S. pneumoniae in PBS buffer [43]. After 48 hours, mice were treated with $10.6 \mathrm{mg} / \mathrm{kg}$ [44] every $8 \mathrm{hrs}$ of levofloxacin [45], a solution of LevoLipo, a solution of $\mathrm{Cp}-1$, or a solution of $\mathrm{Cp}-1$ LevoLipo via subcutaneous 
UNDERGRADUATE RESEARCH IN NATURAL AND CLINICAL SCIENCE AND TECHNOLOGY (URNCST) JOURNAL Read more URNCST Journal articles and submit your own today at: https://www.urncst.com

injection (Figure 4). To assess potential bacteriophage, levofloxacin, or bi-therapy system side effects, mice behavior, grooming, activity, and stool samples would be monitored [34-36] (Figure 4).

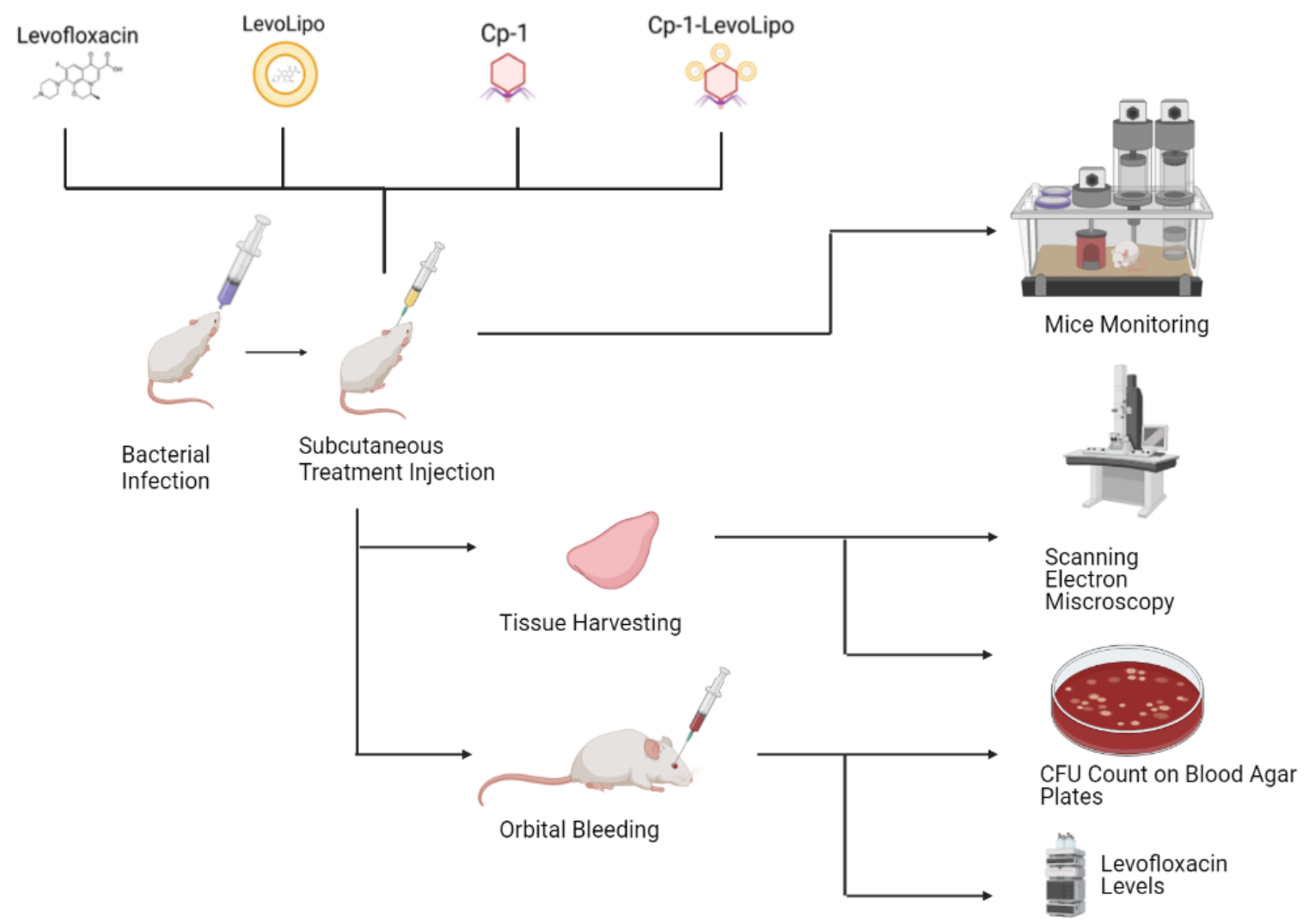

Figure 4. In vivo assessment of Cp-1 LevoLipo bi-therapy system's ability to kill $S$. pneumoniae. BALB/cByJ mice would be infected with bacteria by intranasal injection and subsequently treated with either Levofloxacin, LevoLipo, Cp-1, or Cp-1LevoLipo via subcutaneous injection. Mice would then be monitored to assess for treatment side effects. Mice lungs and nasal septum would be harvested and either homogenized and plated on blood agar plates to measure bacterial CFUs or analyzed by SEM. Finally, mice blood would be collected and used to measure Cp-1 bacteriophage levels and measure levofloxacin blood levels.

To determine bacterial colonization, the mouse nasal septum and lungs were harvested and homogenized. Samples would be serially diluted and plated onto tryptic soy agar with $5 \%$ sheep blood, from which the colony forming unit (CFU) count of each sample would be determined [10]. Additionally, tissue samples harvested would be assessed by scanning electron microscopy (SEM) to evaluate biofilm persistence [10] (Figure 4). Next, $S$. pneumoniae $\mathrm{CFU}$ in the blood would be determined by collecting blood samples 48 hours post-bacterial inoculation via orbital bleeding [43] and plating serial dilutions onto blood agar plates as described above (Figure 4). These blood samples would also be used to determine levofloxacin blood levels via high performance liquid chromatography (HPLC) as described in [45,46] (Figure 4) and $\mathrm{Cp}-1$ bacteriophage levels by co-incubating the bacteriophages with $S$. pneumoniae bacteria on blood agar plates in a technique called Double Agar Overlay [47,48].

\section{Results}

For the antibiogram assay, it is expected that the disks containing Cp-1 LevoLipo will have less bacterial growth around them, compared to the other treatments. Additionally, LevoLipo or levofloxacin alone should have similar sized growth inhibition zones, as the antibiotic delivery by the liposomes should not alter its efficiency. It is expected that only the $\mathrm{Cp}-1$ phages and the $\mathrm{Cp}-1$ LevoLipo complexes to have growth inhibition regions in the biofilm antibiogram assay, where $\mathrm{Cp}-1$ LevoLipo complexes would have the larger inhibition regions. For the in vivo experiments, mice treated with the $\mathrm{Cp}-1$ LevoLipo are expected to have minimal side effects, as monitored by levofloxacin blood levels and mice general health conditions and have the least $S$. pneumoniae present in tissues samples following CFU counting after plating and SEM imaging. 
UNDERGRADUATE RESEARCH IN NATURAL AND CLINICAL SCIENCE AND TECHNOLOGY (URNCST) JOURNAL Read more URNCST Journal articles and submit your own today at: https://www.urncst.com

\section{Discussion}

Phage therapy is becoming a promising treatment alternative for bacterial infections [49]. Since its discovery, extensive research has been conducted to utilize bacteriophage as a potential therapy in the midst of widespread use of antibiotics and rising antimicrobial resistance (AMR) [50]. However, there must be some considerations regarding phage therapy experimentation since several reports of successful phage therapy were tested in humans [50] came with limitations. For instance, there were neutralizing antibodies that appeared in humans after administering phages [51]. These antibodies interfere with treatment but could be solved by administering higher titers of phages. Rapid clearance of phages from the bloodstream is another major limitation in humans. Some phage therapeutics that have failed in mice showed phages being cleared by the spleen, liver, and kidneys [52]. Therefore, there should be careful examination of phage strains that would stay in circulation longer and avoid being recognized by filtering organs when choosing the bacteriophage. In addition, optimizing phage preparation before an injection is of high importance to clear off any host bacteria or debris. Very pure lysates need to be prepared to prevent any endotoxins or live bacteria into the body.

Bacteriophages are effective agents to fight against bacteria and have proven to be a better alternative to antibiotics [53]. However, to improve the efficacy even further, a co-therapy treatment would be experimented to administer both bacteriophages and antibiotics. If the bacterium acquires resistance to phages, it is unlikely for that mutation also to cause resistance to antibiotics as well and vice versa. Thus, the probability of acquiring double mutations to resist both bacteriophages and antibiotics is unlikely within a single bacterium cell. It would likely take $10^{13}$ bacterial divisions for such a double mutation to occur [51,54]. This low probability suggests that coadministration of antibiotics and phage therapy could prevent resistance in S. pneumoniae.

The chosen bacteriophage is a lytic $\mathrm{Cp}-1$ family of phages that targets S. pneumoniae [55]. Cp-1 bacteriophages can encode for Cpl-1 lysozyme which is a glycosidase that cleaves the glycosidic bonds in complex sugars [56-58], which allows them to be very efficient in disintegrating the $S$. pneumoniae biofilms $[28,59]$. Cp-1 bacteriophages would help eliminate biofilm-specific antibiotic resistance to allow for the effective deliverance of antibiotics as a co-therapy treatment option.

There are many advantages with the use of liposomes as carriers for the antibiotics in this theorized system. Liposomes provide stability and protection from an unwanted breakdown in the body [60]. This helps by increasing circulation time and prevents repeated administration or high dose concentrations [37]. They also provide targeted delivery and controlled release of drugs. A positively charged liposome would target a negatively charged bacterial cell wall through electrostatic interactions $[60,61]$. The physicochemical properties would help in the accumulation of drugs at infected sites and direct interaction with bacteria [39]. While these liposomes could deliver antibiotics to other bacteria in the region, the bulk of antibiotic delivery would occur at the $S$. pneumoniae infection due to bacteriophage-directed therapy. This should prevent side effects associated with wide-spread antimicrobial treatment such as diarrhea.

Although the phages and antibiotics could be administered separately, it was decided that they would be delivered together as part of the improved system. Liposomes that contain the antibiotics would fuse with bacteriophages in hopes of targeting and aggregating bacteriophages at the site of $S$. pneumoniae, allowing for the localization of antibiotics. Thus, the targeted drug delivery system via bacteriophage would improve the effectiveness of the delivery while lowering the toxicity of the antibiotics on normal healthy tissues [60]. The bitherapy system would increase biofilm penetration, lower off-target toxicity, and improve the overall efficacy.

The presence of levofloxacin-resistant $S$. pneumoniae might render the antibiotic ineffective, and thus, the expectation for the bacteriophage is to eliminate these strains. Only a few strains inhabiting the respiratory tract are typically resistant to levofloxacin. Hence, the intention to choose levofloxacin as the antibiotic to study the efficiency of the bacteriophage-liposomes complexes was to prove that this model would overcome the challenge that levofloxacin would have if administered alone. Since levofloxacin is widely used as a treatment for respiratory infection, a larger group of patients who are undergoing that treatment could be impacted. If the bacteriophageliposomal delivery of levofloxacin could eliminate levofloxacin-resistant $S$. pneumoniae by targeting the biofilm, a more effective therapy could be developed.

\section{Conclusions}

The rise of antibiotic resistance among $S$. pneumoniae has driven the research of a possible synergistic therapy. While there are no direct therapies against $S$. pneumoniae biofilm, bacteriophages are very attractive therapeutic agents that effectively target pathogenic bacteria, safe for the human body, and highly modifiable to combat newly emerging bacterial threats [62]. This approach would act as a stepping-stone in commencing $\mathrm{Cp}-1$ LevoLipo clinical trials. While the project's primary value stems from increased efficacy and biofilm elimination, the bi-therapy also diminishes dosage-related toxicities of antibiotics through bacteriophage-directed localization. In addition to its many benefits, the use of bacteriophages could significantly reduce healthcare costs [63]. Furthermore, the potential use of bacteriophages-liposomes complexes could be translated to treat respiratory infections in humans after confirming its efficacy in vitro and in vivo studies. Overall, it reduces the burden of new antibiotic development in the 
UNDERGRADUATE RESEARCH IN NATURAL AND CLINICAL SCIENCE AND TECHNOLOGY (URNCST) JOURNAL Read more URNCST Journal articles and submit your own today at: https://www.urncst.com

long-term as it allows us to reuse pre-existing antibiotics that were rendered ineffective and eliminates one of the drivers of antibiotic-resistance mutations: biofilm.

\section{List of Abbreviations Used}

AMR: antimicrobial resistance

CFU: colony forming unit

Cp-1 LevoLipo: Cp-1 bacteriophage carrying LevoLipo

CTAB: cetyltrimethylammonium bromide

DNA: deoxyribonucleic acid

DOPC: 1,2-dioleoyl-sn-glycerophosphocholine

DOTAP: 1,2-dioleoyl-3-trimethylammonium propane

chloride

LevoLipo: liposome containing levofloxacin

PBS: phosphate-buffered saline

SEM: scanning electron microscopy

TEM: transmitted electron microscopy

\section{Conflicts of Interest}

The authors declare that they have no conflicts of interest.

\section{Ethics Approval and/or Participant Consent}

No ethics approval and/or participant consent was required as this is a proposed protocol. If the experiments were to ever be done, they would require such approval.

\section{Authors' Contributions}

All authors have contributed equally to this research.

EA: made contributions to the literature research, drafted the manuscript, and gave final approval of the version to be published.

SA: made contributions to the design of the study, drafted the manuscript, and gave final approval of the version to be published.

AGL: made contributions to the design of the study, drafted the manuscript, and gave final approval of the version to be published.

DJ: made contributions to the literature research, drafted the manuscript, and gave final approval of the version to be published.

\section{Acknowledgements}

Figures were created using BioRender.com. We thank the Translational and Molecular Medicine program from the Faculty of Medicine of the University of Ottawa for sponsoring us.

\section{Funding}

This study was funded for publication fees by the Translational and Molecular Medicine program of the Faculty of Medicine of the University of Ottawa.

\section{References}

[1] Fischer Walker CL, Rudan I, Liu L, Nair H, Theodoratou E, Bhutta ZA, et al. Global burden of childhood pneumonia and diarrhoea. The Lancet. 2013 Apr 20;381(9875):1405-16. https://doi.org/10.1016/ S0140-6736(13)60222-6

[2] Launes C, De-Sevilla MF, Selva L, Garcia-Garcia JJ, Pallares R, Muñoz-Almagro C. Viral coinfection in children less than five years old with invasive pneumococcal disease. Pediatric Infectious Disease Journal. 2012 Jun;31(6):650-3. http://doi.org/10.1097/ INF.0b013e $31824 \mathrm{f} 25 \mathrm{~b} 0$

[3] Infante AJ, McCullers JA, Orihuela CJ. Mechanisms of redisposition to neumonia: Infants, the elderly, and viral infections. Streptococcus Pneumoniae: Molecular Mechanisms of Host-Pathogen Interactions. 2015; 363-82. https://doi.org/10.1016/B978-0-12-410530-0 $.00019-3$

[4] Chao Y, Marks LR, Pettigrew MM, Hakansson AP. Streptococcus pneumoniae biofilm formation and dispersion during colonization and disease. Frontiers in Cellular and Infection Microbiology. 2014 Apr 1;4. https://doi.org/10.3389/fcimb.2014.00194

[5] Bogaert D, De Groot R, Hermans PWM. Streptococcus pneumoniae colonisation: The key to pneumococcal disease. Lancet Infectious Diseases; 2004 Mar 1;4(3):144-54. https://doi.org/10.1016/S1473-3099(04) 00938-7

[6] de Gans J, van de Beek D. Dexamethasone in adults with bacterial meningitis. New England Journal of Medicine. 2002 Nov 14;347(20):1549-56. https://doi.org/10.1056/NEJMoa021334

[7] Worsøe L, Cayé-Thomasen P, Brandt CT, Thomsen J, Østergaard C. Factors associated with the occurrence of hearing loss after pneumococcal meningitis. Clinical Infectious Diseases. 2010 Oct 15;51(8):917-24. https://doi.org/10.1086/656409

[8] Weiser JN, Ferreira DM, Paton JC. Streptococcus pneumoniae: Transmission, colonization and invasion. Nature Reviews Microbiology. 2018;16:355-67. https://doi.org/10.1038/s41579-018-0001-8

[9] van der Poll T, Opal SM. Pathogenesis, treatment, and prevention of Pneumococcal pneumonia. The Lancet. 2009 Oct 31;374(9700):1543-56. https://doi.org/ 10.1016/S0140-6736(09)61114-4

[10] Marks LR, Iyer Parameswaran G, Hakansson AP. Pneumococcal interactions with epithelial cells are crucial for optimal biofilm formation and colonization in vitro and in vivo. Infection and Immunity. 2012 Aug;80(8):2744-60. https://doi.org/10.1128/IAI.00488-12

[11] Donlan RM. Biofilms: Microbial life on surfaces. Emerging Infectious Diseases. 2002 Sep;8(9):881-90. https://doi.org/10.3201/eid0809.020063

[12] Yasir M, Willcox MDP, Dutta D. Action of antimicrobial peptides against bacterial biofilms. Materials. 2018;11:2468. https://doi.org/10.3390/ma11122468 
UNDERGRADUATE RESEARCH IN NATURAL AND CLINICAL SCIENCE AND TECHNOLOGY (URNCST) JOURNAL Read more URNCST Journal articles and submit your own today at: https://www.urncst.com

[13]Lipsitch M, Dykes JK, Johnson SE, Ades EW, King J, Briles DE, et al. Competition among Streptococcus pneumoniae for intranasal colonization in a mouse model. Vaccine. 2000 Jun 15;18(25):2895-901. https://doi.org/10.1016/S0264-410X(00)00046-3

[14] Mizrachi-Nebenzahl Y, Lifshitz S, Teitelbaum R, Novick S, Levi A, Benharroch D, et al. Differential activation of the immune system by virulent Streptococcus pneumoniae strains determines recovery or death of the host. Clinical and Experimental Immunology. 2003 Oct ;134(1):23-31. http://doi.org/ 10.1046/j.1365-2249.2003.02261.x

[15] Orihuela CJ, Gao G, McGee M, Yu J, Francis KP, Tuomanen E. Organ-specific models of Streptococcus pneumoniae disease. Scandinavian Journal of Infectious Diseases. 2003;35(9):647-52. http://doi.org/ 10.1080/00365540310015854

[16] Mandell LA, Marrie TJ, Grossman RF, Chow AW, Hyland RH. Canadian guidelines for the initial management of community-acquired pneumonia: An evidence-based update by the Canadian Infectious Diseases Society and the Canadian Thoracic Society. Clinical Infectious Diseases. 2000;31:383-421. https://doi.org/10.1086/323024

[17] Izadi E, Afshan G, Patel RP, Rao VM, Liew K Bin, Affandi MMRMM, et al. Levofloxacin: Insights into antibiotic resistance and product quality. Frontiers in Pharmacology. 2019;10:881. https://doi.org/10.3389/ fphar.2019.00881

[18] Oggioni MR, Trappetti C, Kadioglu A, Cassone M, Iannelli F, Ricci S, et al. Switch from planktonic to sessile life: A major event in pneumococcal pathogenesis. Molecular Microbiology. 2006 Sep;61(5):1196-210. https://doi.org/10.1111/j.1365-2958.2006.05310.x

[19] Muñoz-Elías EJ, Marcano J, Camilli A. Isolation of Streptococcus pneumoniae biofilm mutants and their characterization during nasopharyngeal colonization. Infection Immunity. 2008 Nov;76(11):5049-61. https://doi.org/10.1128/IAI.00425-08

[20] Trappetti C, Kadioglu A, Carter M, Hayre J, Iannelli F, Pozzi G, et al. Sialic acid: A preventable signal for pneumococcal biofilm formation, colonization, and invasion of the host. Journal of Infectious Diseases. 2009 May 15;199(10):1497-505. https://doi.org/ $10.1086 / 598483$

[21] De Kievit TR, Parkins MD, Gillis RJ, Srikumar R, Ceri $\mathrm{H}$, Poole K, et al. Multidrug efflux pumps: Expression patterns and contribution to antibiotic resistance in Pseudomonas aeruginosa biofilms. Antimicrobial Agents and Chemotherapy. 2001 Jun;45(6):1761-70. https://doi.org/10.1128/AAC.45.6.1761-1770.2001

[22] Hall CW, Mah TF. Molecular mechanisms of biofilmbased antibiotic resistance and tolerance in pathogenic bacteria. FEMS Microbiology Reviews. Oxford University Press; 2017;41:276-301. https://doi.org/ $\underline{10.1093 / \mathrm{femsre} / \mathrm{fux} 010}$

Jung et al. | URNCST Journal (2021): Volume 5, Issue 10 DOI Link: https://doi.org/10.26685/urncst.294
[23] Cherazard R, Epstein M, Doan TL, Salim T, Bharti S, Smith MA. Antimicrobial resistant Streptococcus pneumoniae: Prevalence, mechanisms, and clinical implications. American Journal of Therapeutics. 2017 May 1;24(3):e361-9. https://doi.org/10.1097/MJT .0000000000000551

[24] Romero-Calle D, Benevides RG, Góes-Neto A, Billington C. Bacteriophages as alternatives to antibiotics in clinical care. Antibiotics. 2019;8(3):138. https://doi.org/10.3390/antibiotics8030138

[25] Lin DM, Koskella B, Lin HC. Phage therapy: An alternative to antibiotics in the age of multi-drug resistance. World Journal of Gastrointestinal Pharmacology and Therapeutics. 2017;8(3):162. https://doi.org/10.4292/wjgpt.v8.i3.162

[26] Alisky J, Iczkowski K, Rapoport A, Troitsky N. Bacteriophages show promise as antimicrobial agents. Journal of Infection. 1998;36:5-15. https://doi.org/ 10.1080/23308249.2016.1241977

[27] Putra RD, Lyrawati D. Interactions between bacteriophages and eukaryotic cells. Scientifica. 2020 Jun 9;2020. https://doi.org/10.1155/2020/3589316

[28] Domenech M, Garciá E, Moscoso M. In vitro destruction of Streptococcus pneumoniae biofilms with bacterial and phage peptidoglycan hydrolases. Antimicrobial Agents and Chemotherapy. 2011 Sep; 55(9):4144-8. https://doi.org/10.1128/AAC.00492-11

[29] Witzenrath M, Schmeck B, Doehn JM, Tschernig T, Zahlten J, Loeffler JM, et al. Systemic use of the endolysin Cpl-1 rescues mice with fatal pneumococcal pneumonia. Critical Care Medicine. 2009;37(2):642-9. https://doi.org/10.1097/CCM.0b013e31819586a6

[30] Morrisette T, Kebriaei R, Lev KL, Morales S, Rybak MJ. Bacteriophage therapeutics: A primer for clinicians on phage-antibiotic combinations. Pharmacotherapy. 2020;40:153-68. https://doi.org/ 10.1002/phar.2358

[31] Knezevic P, Curcin S, Aleksic V, Petrusic M, Vlaski L. Phage-antibiotic synergism: A possible approach to combatting Pseudomonas aeruginosa. Research in Microbiology. 2013 Jan;164(1):55-60. https://doi.org/ 10.1016/j.resmic.2012.08.008

[32] Kirby AE. Synergistic action of gentamicin and bacteriophage in a continuous culture population of Staphylococcus aureus. PLoS One. 2012 Nov 30;7(11). https://doi.org/10.1371/journal.pone.0051017

[33] H P-A, A A, P C. Targeted delivery of antibiotics using liposomes and nanoparticles: Research and applications. International Journal of Antimicrobial Agents. 2000;13(3):155-68. https://doi.org/10.1016/ S0924-8579(99)00121-1

[34]Z D-K, A D-J. Liposomes as delivery systems for antibiotics. International Journal of Pharmaceutics. 2010 Mar;387(1-2):187-98. https://doi.org/10.1016/ j.ijpharm.2009.11.033 
UNDERGRADUATE RESEARCH IN NATURAL AND CLINICAL SCIENCE AND TECHNOLOGY (URNCST) JOURNAL Read more URNCST Journal articles and submit your own today at: https://www.urncst.com

[35] A GG, Z H. Liposomes for antibiotic encapsulation and delivery. ACS Infectious Diseases. 2020 May 8;6(5):896-908. https://doi.org.proxy.bib.uottawa.ca/ 10.1021/acsinfecdis.9b00357

[36] M L, C D, N G, Y T, X M, H S, et al. Composition design and medical application of liposomes. European Journal of Medicinal Chemistry. 2019 Feb 15;164: 640-53. https://doi.org/10.1016/j.ejmech.2019.01.007

[37]Lila ASA, Ishida T. Liposomal delivery systems: Design optimization and current applications. Biological and Pharmaceutical Bulletin. 2017;40:1-10. https://doi.org/10.1248/bpb.b16-00624

[38] Ngweniform P, Abbineni G, Cao B, Mao C. Selfassembly of drug-loaded liposomes on genetically engineered target-recognizing M13 phage: A novel nanocarrier for targeted drug delivery. Small. 2009 Sep 4;5(17):1963-9. https://doi.org/10.1002/smll.200801902

[39] Drulis-Kawa Z, Dorotkiewicz-Jach A. Liposomes as delivery systems for antibiotics. International Journal of Pharmaceutics; 2010;387:187-98. Available from: https://pubmed.ncbi.nlm.nih.gov/19969054/

[40] Martín AC, López R, García P. Pneumococcal bacteriophage $\mathrm{Cp}-1$ encodes its own protease essential for phage maturation. Journal of Virology. 1998 Apr;72(4):3491-4. https://doi.org/10.1016/j.ijpharm .2009 .11 .033

[41] Brunner J, Skrabal P, Hausser H. Single bilayer vesicles prepared without sonication physico-chemical properties. Biochimica et Biophysica Acta Biomembranes - Journals. 1976 Dec 2;455(2):322-31. https://doi.org/10.1016/0005-2736(76)90308-4

[42] Petsong K, Uddin MJ, Vongkamjan K, Ahn J. Combined effect of bacteriophage and antibiotic on the inhibition of the development of antibiotic resistance in Salmonella typhimurium. Food Science and Biotechnology. 2018 Aug 1;27(4):1239-44. https://doi.org/10.1007/s10068-018-0351-z

[43] Brown LR, Caulkins RC, Schartel TE, Rosch JW, Honsa ES, Schultz-Cherry S, et al. Increased zinc availability enhances initial aggregation and biofilm formation of Streptococcus pneumoniae. Frontiers in Cellular and Infection Microbiology. 2017 Jun 7;7:233. https://doi.org/10.3389/fcimb.2017.00233

[44] Hsu A, Aronoff DM, Phipps J, Goel D, Mancuso P. Leptin improves pulmonary bacterial clearance and survival in ob/ob mice during pneumococcal pneumonia. Clinical and Experimental Immunology. 2007 Nov 1;150(2):332-9. https://doi.org/10.1111/j.1365-2249 $.2007 .03491 . \mathrm{x}$

[45] Onyeji CO, Bui KQ, Owens RC, Nicolau DP, Quintiliani $\mathrm{R}$, Nightingale $\mathrm{CH}$. Comparative efficacies of levofloxacin and ciprofloxacin against Streptococcus pneumoniae in a mouse model of experimental septicaemia. International Journal of Antimicrobial Agents. 1999 Jul 1;12(2):107-14. https://doi.org/ $\underline{10.1016 / \mathrm{S} 0924-8579(98) 00087-9}$

Jung et al. | URNCST Journal (2021): Volume 5, Issue 10 DOI Link: https://doi.org/10.26685/urncst.294
[46] Scaglione F, Mouton JW, Mattina R, Fraschini F. Pharmacodynamics of levofloxacin and ciprofloxacin in a murine pneumonia model: Peak concentration/MIC versus area under the curve/MIC ratios. Antimicrobial Agents Chemotherapy. $2003 \mathrm{Sep}$ 1;47(9):2749-55. https://doi.org/10.1128/AAC.47.9 $.2749-2755.2003$

[47] Wong FA, Juzwin SJ, Flor SC. Rapid stereospecific high-performance liquid chromatographic determination of levofloxacin in human plasma and urine. Journal of Pharmaceutical and Biomedical Analysis. 1997 Mar 1;15(6):765-71. https://doi.org/ 10.1016/S0731-7085(96)01890-0

[48] Kropinski AM, Mazzocco A, Waddell TE, Lingohr E, Johnson RP. Enumeration of bacteriophages by double agar overlay plaque assay. Methods in Molecular Biology. 2009;501:69-76. https://doi.org/10.1007/9781-60327-164-6_7

[49] Duyvejonck H, Merabishvili M, Pirnay JP, De Vos D, Verbeken G, Van Belleghem J, et al. Development of a qPCR platform for quantification of the five bacteriophages within bacteriophage cocktail 2 (BFC2). Scientific Reports. 2019 Dec 1;9(1):1-10. https://doi.org/10.1038/s41598-019-50461-0

[50] Barrow PA, Soothill JS. Bacteriophage therapy and prophylaxis: Rediscovery and renewed assessment of potential. Trends in Microbiology.1997;5:268-71. https://doi.org/10.1016/S0966-842X(97)01054-8

[51] Sulakvelidze A, Alavidze Z, Morris J. Bacteriophage therapy. Antimicrobial Agents and Chemotherapy. 2001;45:649-59. https://doi.org/10.1128/AAC.45.3 $.649-659.2001$

[52] Carlton RM. Phage therapy: Past history and future prospects.Archivum Immunologiae et Therapiae Experimentalis. 1999;47. Available from: https://pubmed.ncbi.nlm.nih.gov/10604231/

[53] Geier MR, Trigg ME, Merril CR. Fate of bacteriophage lambda in non-immune germ-free mice. Nature. 1973;246(5430):221-3. https://doi.org/10.1038 $1246221 \mathrm{a} 0$

[54] Golding I. Infection by bacteriophage lambda: An evolving paradigm for cellular individuality. Current Opinion in Microbiology. 2018;43:9-13. https://doi.org/10.1016/j.mib.2017.09.014

[55] Grigonyte AM, Hapeshi A, Constantinidou C, Millard A. Modification of bacteriophages to increase their association with lung epithelium cells in vitro. Pharmaceuticals. 2021 Apr 1;14(4). https://doi.org/ 10.3390/ph14040308

[56] García P, Martin AC, López R. Bacteriophages of Streptococcus pneumoniae: A molecular approach. Microbial Drug Resistance. 1997;3(2):165-76. https://doi.org/10.1089/mdr.1997.3.165 
UNDERGRADUATE RESEARCH IN NATURAL AND CLINICAL SCIENCE AND TECHNOLOGY (URNCST) JOURNAL Read more URNCST Journal articles and submit your own today at: https://www.urncst.com

[57] Hermoso JA, Monterroso B, Albert A, Galán B, Ahrazem O, García P, et al. Structural basis for selective recognition of pneumococcal cell wall by modular endolysin from phage $\mathrm{Cp}-1$. Structure. 2003 Oct 1;11(10):1239-49. https://doi.org/10.1016/i.str .2003 .09 .005

[58] Bustamante N, Campillo NE, García E, Gallego C, Pera B, Diakun GP, et al. Cpl-7, a lysozyme encoded by a pneumococcal bacteriophage with a novel cell wall-binding motif. Journal of Biological Chemistry. 2010 Oct 22;285(43):33184-96. https://doi.org/10 $.1074 /$ jbc.M110.154559

[59] Garcia JL, Garcia E, Arraras A, Garcia P, Ronda C, Lopez R. Cloning, purification, and biochemical characterization of the pneumococcal bacteriophage Cp-1 lysin. Journal of Virology. 1987. https://doi.org/ 10.1128/jvi.61.8.2573-2580.1987

[60] Donlan RM. Preventing biofilms of clinically relevant organisms using bacteriophage. Trends in Microbiology. 2009;17:66-72. https://doi.org/10.1016/ j.tim.2008.11.002
[61] Ferreira M, Ogren M, Dias JNR, Silva M, Gil S, Tavares L, et al. Liposomes as antibiotic delivery systems: A promising nanotechnological strategy against antimicrobial resistance. Molecules. $2021 \mathrm{Apr}$ 1;26(7). https://doi.org/10.3390/molecules26072047

[62] Gao W, Chen Y, Zhang Y, Zhang Q, Zhang L. Nanoparticle-based local antimicrobial drug delivery. Advanced Drug Delivery Reviews. 2018;127:46-57. https://doi.org/10.1016/j.addr.2017.09.015

[63] Furfaro LL, Payne MS, Chang BJ. Bacteriophage therapy: Clinical trials and regulatory hurdles. Frontiers in Cellular and Infection Microbiology. 2018;8:376. https://doi.org/10.3389/fcimb.2018.00376

[64] Principi N, Silvestri E, Esposito S. Advantages and limitations of bacteriophages for the treatment of bacterial infections. Frontiers in Pharmacology. 2019;10:513. https://doi.org/10.3389/fphar

\section{Article Information}

Managing Editor: Jeremy Y. Ng

Peer Reviewers: Bi-ru Amy Yeung, Foram Vyas

Article Dates: Received Jun 14 21; Accepted Sep 15 21; Published Oct 1321

\section{Citation}

Please cite this article as follows:

Jung D, Gaudreau-Lapierre A, Alnahhas E. Bacteriophage-liposomes complex, a bi-therapy system to target Streptococcus pneumonia and biofilm: A research protocol. URNCST Journal. 2021 Oct 13: 5(10).

https://urncst.com/index.php/urncst/article/view/294

DOI Link: https://doi.org/10.26685/urncst.294

\section{Copyright}

(C) David Jung, Antoine Gaudreau-Lapierre, Emran Alnahhas. (2021). Published first in the Undergraduate Research in Natural and Clinical Science and Technology (URNCST) Journal. This is an open access article distributed under the terms of the Creative Commons Attribution License (https://creativecommons.org/licenses/by/4.0/), which permits unrestricted use, distribution, and reproduction in any medium, provided the original work, first published in the Undergraduate Research in Natural and Clinical Science and Technology (URNCST) Journal, is properly cited. The complete bibliographic information, a link to the original publication on http://www.urncst.com, as well as this copyright and license information must be included.
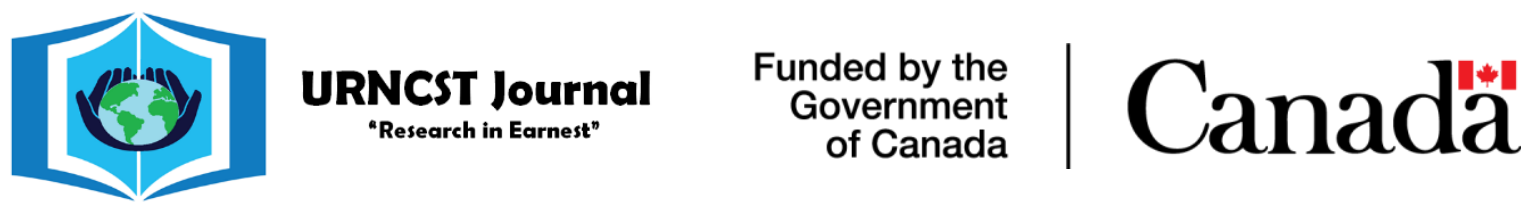

Do you research in earnest? Submit your next undergraduate research article to the URNCST Journal!

| Open Access | Peer-Reviewed | Rapid Turnaround Time | International |

| Broad and Multidisciplinary | Indexed | Innovative | Social Media Promoted |

Pre-submission inquiries? Send us an email at info@ urncst.com | Facebook, Twitter and LinkedIn:

@URNCSTSubmit YOUR manuscript today at https://www.urncst.com! 